Bahterasia: Jurnal Ilmiah Pendidikan Bahasa dan Sastra Indonesia

http://journal.umsu.ac.id/sju/index.php/bahterasia

\title{
PENGGUNAAN PUZZLE DALAM MEMAHAMI KOHESI DAN KOHE-RENSI WACANA PADA MAHASISWA SEMESTER 1 PADA PRODI PENDIDIKAN BAHASA DAN SASTRA INDONESIA FKIP UMSU
}

\section{Oktavia Lestari $\mathbf{P}^{凶}$}

Prodi Pendidikan Bahasa dan Sastra Indonesia, Fakultas Keguruan dan Ilmu Pendidikan, Universitas Muhammadiyah Sumatera Utara, Indonesia

\section{Info Artikel Abstrak}

\begin{tabular}{l}
\hline \\
Sejarah Artikel: \\
Diterima \\
Oktober 2019 \\
Disetujui \\
Desember 2019 \\
Dipublikasikan \\
Februari 2020
\end{tabular}

Kemampuan memahami wacana tidak terlepas dari penggunaan Puzzle (kemampuan penguasaan kosa kata). Kemampuan memahami wacana mahasiswa siswa harus didukung oleh kemampuan penguasaan kosa katanya. Penggunaan puzzle sebagai bantuan, mampu membantu dan meningkatkan dalam proses memahami wacana. Disisi lain puzzle juga dapat memudahkan mahasiswa dalam memahami wacana yang kohesi dan koherensi, serta membuat mahasiswa lebih percaya diri atas jawabannya serta penggunaan puzzle mempermudah memahami wacana, sehingga wacana menjadi sangat menarik. Puzzle dirancang untuk mengajarkan keterampilan seperti mengenali bentuk, ukuran, jumlah, warna, kesamaan dan perbedaan. Penelitian yang digunakan adalah eksperimen (post test dan pre test). Berdasarkan hasil penelitian yang diperoleh yang telah dijabarkan pada bab sebelumnya, dapat dikatakan tingkat penggunaan Puzzle pada mahasiswa Semester 1 FKIP UMSU berada pada kategori baik di mana nilai rata-rata siswa 71,4 .

Kata Kunci: Pengertian Puzzle, Kohesi, Koherensi, Wacana

\section{Abstract}

The ability to understand discourse cannot be separated from the use of Puzzles (the ability to master vocabulary). The ability to understand students' student discourses must be supported by their vocabulary mastery skills. The use of puzzle as an aid, is able to help and improve in the process of understanding discourse. On the other hand, puzzles can also facilitate students in understanding discourse that is cohesive and coherent, and makes students more confident in their answers and the use of puzzles makes it easier to understand discourse, so that discourse becomes very interesting. Puzzles are designed to teach skills such as recognizing shapes, sizes, quantities, colors, similarities and differences. The research used was experimental (post test and pre test). Based on the research results obtained which have been described in the previous chapter, it can be said that the level of use of Puzzle for 1st FKIP UMSU students is in the good category where the average score of students is 71.4

Keywords: Understanding Puzzles, Cohesion, Coherence, Discourse

\begin{tabular}{lr}
\hline Alamat korespondensi: & p-ISSN xxxx-Xxxx \\
Kampus UMSU Jalan Kapten Muchtar Basri No 3, & e-ISSN xxxx-Xxxx \\
Medan-Sumatera Utara, 20238 & \\
e-mail: jurnalbahterasia@umsu.ac.id. & \\
\hline
\end{tabular}




\section{PENDAHULUAN}

Kemampuan memahami wacana tidak terlepas dari penggunaan Puzzle (kemampuan penguasaan kosa kata). Kemampuan memahami wacana mahasiswa siswa harus didukung oleh kemampuan penguasaan kosa katanya. Salah satu syarat memahami isi wacana yaitu pengetahuan mengenai kosa kata. Pengalaman menunjukkan bahwa para mahasiswa atau pelajar yang mempunyai kosa kata yang baik dan perbendaharaan katakata yang memadai, tidak akan menemukan kesulitan dalam pemahaman.Maka sebaiknya mahasiswa diajarkan atau difasilitasi agar memiliki kosa kata yang baik/ memadai sebelum belajar memahami wacana. Hal ini menunjuk pada kemampuan untuk memahami maksud dan pikiran seseorang baik secara eksplisit maupun implisit yang diungkapkan secara tertulis melalui wacananya.

Penggunaan puzzle sebagai bantuan, mampu membantu dan meningkatkan dalam proses memahami wacana. Disisi lain puzzle juga dapat memudahkan mahasiswa dalam memahami wacana yang kohesi dan koherensi, serta membuat mahasiswa lebih percaya diri atas jawabannya serta penggunaan puzzle mempermudah memahami wacana, sehingga wacana menjadi sangat menarik.

Beragamamnya media pembelajaran, membuat puzzle menjadi kemudahaan bagi pengajar serta mahasiswa dalam menggunakannya untuk mencapai tujuan proses pembelajaran yang lebih menyenangkan. Selain itu pembelajaran dengan menggunakan media diharapkan menjadi bagian dalam upaya meningkatkan hasil belajar mahasiswa. Dengan adanya puzzle dapat dimanfaatkan teknologi, maka materi ajar yang disampaikan pengajarakan inovatif dibandingkan secara konvensional. Puzzle merupakan komponen intruksional yang meliputi pesan, orang, dan peralatan. Media memiliki banyak makna baik dilihat secara terbatas maupun secara luas.

Puzzle dirancang untuk mengajarkan keterampilan sepertimengenali bentuk, ukuran, jumlah, warna, kesamaan dan perbedaan (Dianne Miller Nielsen, 2008:98). Dikutip dari(http://adekaedutoysandcraft.com/page_id=337) : puzzle dapat berupa jigsaw atau bentuk 3 dimensi, menganut asaspotongan homogen ataupun acak, bisa berupa kepingan besar ataukecil atau gabungan keduanya, dapat berupa gambar yang dipecahatau komponen yang harus digabungkan, serta dapat pula disusunpada landasan/bingkai tertentu atau harus dirakit menjadi bentuk tertentu.

Puzzle disini adalah puzzle bentuk 3 dimensi yang terbuat darikayu jati atau biasa disebut sebagai teakwood puzzle. Teak berarti jati danwood berarti kayu. Bentuk teakwood puzzle ada beraneka ragam dapat mencapai 30 jenis, antara lain bentuk bola, bintang, bola bintang, bintanglaut, segi enam, apollo, roket, candi dan lain-lain.

Istilah kohesi dan koherensi yang dimaksud dalam penelitian ini mengandung pengertian, kohesi adalah keterpaduan bentuk sedangkan koherensi adalah kepaduan makna. Teks atau wacana yang kohesif berarti setiap unsur lahirnya terpadu secara internal dalam satuan teks tersebut. Tegasnya, setiap komponen teks lahir, misalnya kata aktual yang didengar atau dibaca, saling terhubung dalam rangkaian. Unsur-unsur komponen lahirnya harus saling tergantung. Kushartanti (2004:96) mengatakan, "kohesi adalah keadaan unsur-unsur bahasa yang saling merujuk dan saling berkaitan secara 
semantis." Junaiyah (2006:24) mengatakan, "Kohesi adalah kepaduan bentuk bahasa yang secara struktural membentuk ikatan sintaksis."

\section{METODE PENELITIAN}

Penelitian ini dilakukan pada mahasiswa semester 1 Prodi Pendidikan Bahasa dan Sastra Indonesia FKIP UMSU. Jenis penelitian ini adalah penelitian eksperimen (post test dan pre test). Populasi dari penelitian ini ada 1 (lima) kelas prodi pendidikan bahasa dan sastra Indonesia semerter 1. Yang berjumlah lebih kurang 45 orang mahasiswa. Kelas A ini menjadi sampel pada penelitian ini Pendidikan Bahasa dan Sastra Indonesia Fakultas Keguruan dan Ilmu Pendidikan Universitas Muhammadiyah Sumatera Utara tahun ajaran $2017 / 2018$.

Langkah-langkah dalam penelitian adalah sebagai berikut: 1) Diawali dengan memberikan proses pembelajaran melalui kemampuan membaca serta memahami wacana pada kelas semester I mengetahui mahasiswa mampu atau tidak memahami wacana yang kohesi dan koherensi, 2) Lalu peneliti membentuk pembagian kelompok kerja/tugas, dengan menggunakan media pembelajaran dan tanpa menggunakan media pembelajaran, 3) Peneliti mengobservasi dengan menggunaan puzzle dalam memahami kohesi dan koherensi wacana pada mahasiswa di kelas eksperimen dan kelas kontrol. Adapun instrumen penelitian ini adalah berupa pre test dan post test yang diberikan kepada mahasiswa dan juga peneliti melakukan pengamatan selama berlangsung proses pembelajaran.

\section{HASIL PENELITIAN DAN PEMBAHASAN}

Penelitian ini dilaksanakan dalam 14 kali pertemuan, dengan materi terlihat pada table berikut ini:

Tabel 1

Pertemuan Materi Perkuliahan pada Pelaksanaan Penelitian

\begin{tabular}{ccc}
\hline Pertemuan & Tanggal & Materi \\
\hline I & 6 Maret 2018 & Kontrak belajar \\
II & 13 Maret 2018 & Puzzle \\
III & 20 Maret 2018 & Penggunaan puzzle \\
IV & 27 Maret 2018 & Materi Kohesi \\
V & 3 April 2018 & Materi Koherensi \\
VI & 10 April 2018 & Jenis-jenis kohesi \\
VII & 17 April 2018 & Wacana \\
VIII & UTS & \\
IX & 3 April 2018 & Memahami kohesi dalam wacana \\
X & 10 April 2018 & Memahami koherensi dalam wacana \\
XI & 17 April 2018 & Menyusun puzzle wacana \\
XII & 24 April 2018 & Memahami isi wacana melalui puzzle \\
XIII & 4 Mei 2018 & Mendiskusikan isi wacana dari penggunaan puzzle \\
XIV & 8 Mei 2018 & secara berkelompok \\
XV & 24 Juni 2018 & Mempresentasi isi wacana dengan menggunakan puzzle \\
XVI & UAS & Kuis \\
\hline
\end{tabular}

Berdasarkan data yang diperoleh dari hasil penelitian dengan jumlah responden 43 orang terdapat skor tertinggi 90 dan skor terendah 40 dengan rata-rata (M) 67,09 dan 
standar deviasi (SD) 8,54. Untuk mengetahui hubungan penguasaan Puzzle dengan kemampuan memahami wacana digunakan rumus korelasi Product moment. korelasi rhitung antara penguasaan Puzzle dengan kemampuan memahami wacana kelas Mahasiswa Semester 1 FKIP UMSU Medan, maka diperoleh: $r=0,425$. Dengan kata lain dapat disimpulkan bahwa antara penguasaan Puzzle dengan kemampuan memahami wacana mempunyai hubungan yang signifikan.

Untuk menguji hipotesis antara variabel penguasaan Puzzle dengan kemampuan memahami wacana digunakan analisis Product Moment dengan angka kasar dari Pearson. Dari hasil analisis korelasi antara variabel $X$ dengan variabel $Y$ diperoleh $r x y=0,425$ sedangkan nilai rtabel pada taraf signifikansi dan $\mathrm{N}=43$ adalah 0,301. Dengan demikian rxy $>$ rtabel atau $0,425>0,301$.

Pada taraf signifikansi dengan $\mathrm{dk}=\mathrm{N}-2=43-2$ di dapat ttabel sebesar 2,01. Setelah dikontribusi ternyata thitung $>$ ttabel atau 3,078>2,01. Dengan demikian hubungan dinyatakan berarti, artinya Ho ditolak dan Ha diterima yang menyatakan "ada hubungan yang positif dan signifikan antara penggunaan "

Penggunaan Puzzle pada Mahasiswa Semester 1 FKIP UMSU termasuk dalam ketegori baik dengan skor tertinggi 85 , terendah 50 , dan rata-rata $=71,74$. Kemampuan memahami wacana siswa kelas Mahasiswa Semester 1 FKIP UMSU termasuk dalam ketegori cukup dengan skor tertinggi 90, terendah 40, dan rata-rata $=67,09$.

Dari hasil analisis data diperoleh rata-rata (M) sebesar 71,4 dan standar deviasi (SD) 9,63 serta Lhitung < Ltabel yaitu 0, $1063<0,1351$ yang berarti data berdistribusi normal. Dari perhitungan data juga ditemukan nilai tertinggi 85 dan nilai terendah 50. Siswa yang berada pada kategori sangat baik sebanyak $16,28 \%$, berada pada kategori baik sebanyak $55,81 \%$, berada pada kategori cukup sebanyak 23,26\%, dan pada kategori kurang sebanyak 4,65\%.

Berdasarkan hasil penelitian yang diperoleh yang telah dijabarkan, dapat dikatakan tingkat penggunaan Puzzle pada mahasiswa Semester 1 FKIP UMSU berada pada kategori baik di mana nilai rata-rata siswa 71,4.

\section{SIMPULAN}

1. Penggunaan Puzzle pada Mahasiswa Semester 1 FKIP UMSU termasuk dalam ketegori baik dengan skor tertinggi 85, terendah 50, dan rata-rata $=71,74$.

2. Kemampuan memahami wacana siswa kelas Mahasiswa SemesterFKIP UMSU termasuk dalam ketegori cukup dengan skor tertinggi 90 , terendah 40, dan rata-rata $=67,09$.

\section{DAFTAR PUSTAKA}

Baxter, J. 2000. "Teaching Girls to Speak Out: An Investigation of the Extent to Which Gender is a Pertinent Discourse for Describing and Assessing Girls' and Boys' Speech in Public Contexts". PhD thesis, The University of Reading.

Baxter, J. 2002. Competing discourses in the classroom: a Post-structuralist Discourse Analysis of girls' and boys' speech in public contexts. London: University of Reading. 
Belsey, C. 1980. Critical Practice. London: Methuen.

Darma, YoceAliah. 2009. AnalisisWacanaKritis. Bandung: YramaWidya.

Eriyanto. 2011. AnalisisWacana: pengantaranalisisteks media. Yogyakarta: LkiS Printing Cemerlang.

Fairclough, Norman. 1998. Language and Power. London and New York: Logman.

Foucault, Michael. 2002. Power / Knowledge. (diterjemahkanolehYudiSantosa). Jogjakarta: BintangBudaya.

Francis, B. 1998. Power Plays: Children's Constructions of Gender, Power and Adult Work. Stoke-on-Trent: Trentham Books.

Santoso, Anang. 2012. StudiBahasaKritis: MenguakBahasaMembongkarKuasa. Bandung: MandarMaju.

Swann, J. and Graddol, D. 1988. "Gender Inequalities in Classroom Talk". English in Education 22: 48-65.

Walkerdine, V. 1990.Schoolgirl Fictions. London: Verso.

Wetherell, M. 1998. Positioning and Interpretative Repertoires: Conversation Analysis and Post-structuralism in Dialogue. Discourse \& Society 9: 387-412 